\title{
Republic of Macedonia - A Timeless Migration Mosaic
}

DOI: $10.11567 /$ met.34.1.2

UDK: 314.15-026.49(497.7)

Pregledni rad

Primljeno: 13.03.2018.

Prihvaćeno: 09.08.2018.

\section{Biljana Apostolovska Toshevska}

Institute of Geography, Faculty of Natural Sciences and Mathematics, University of Ss.

Cyril and Methodius, Skopje

biljana.apostolovska@gmail

Mirjanka Madjevikj

Institute of Geography, Faculty of Natural Sciences and Mathematics, University of Ss.

Cyril and Methodius, Skopje

mira.madzevikj@gmail.com

\section{Marija Ljakoska}

Institute of Geography, Faculty of Natural Sciences and Mathematics, University of Ss. Cyril and Methodius, Skopje

ljakoska.marija@yahoo.com

\section{Svemir Gorin}

Institute of Geography, Faculty of Natural Sciences and Mathematics, University of Ss. Cyril and Methodius, Skopje

svemirgorin@gmail.com

\section{Ivan Radevski}

Institute of Geography, Faculty of Natural Sciences and Mathematics, University of Ss.

Cyril and Methodius, Skopje

radevskiivan3@gmail.com

\section{Olgica Dimitrovska}

Institute of Geography, Faculty of Natural Sciences and Mathematics, University of Ss.

Cyril and Methodius, Skopje

olgica.dimitrovska@gmail.com

\section{SUMMARY}

This paper has the intention to depict the spatial and temporal dimensions of international migration in Macedonia. The observations are based on historical documents, from archive data and published papers all the way to contemporary records and data on immigration and emigration, as well as on interviews with Macedonian citizens who live abroad. 
Emigration and immigration are reviewed in two periods: first, from the earliest settlements in the area of today's Republic of Macedonia until its independence in 1991, and second, the period from proclaiming its independence until today. Only the major migration flows that left their mark in the spatial, economic, social and cultural organization of the country are presented in the paper. Migration flows in the period of the Ottoman Empire, which have had great influence on the current demographic composition of the population of Macedonia, are given emphasis. However, an overview is also provided for other immigration flows towards Macedonia throughout history until today.

A part of the paper refers to recent history and emigration after 1964, as well as to the emigration of Macedonian citizens in the period after 1991. Although estimates have been made, the question of exactly how many Macedonian citizens live outside their home country remains unanswered. At the same time, the paper touches upon an interesting topic of intensive foreigner immigration flows towards Macedonia in the period after its independence, especially from Albania, Turkey and Kosovo. Contrary to the immigration flows of foreigners, the emigration flows of Macedonian citizens are highlighted. Therefore, the positive net migration in the country is due to the immigration of foreigners with temporary and extended stay. At the same time, Macedonia is a part of the Balkan migrants' route for the migrants from Asian and African countries.

KEY WORDS: emigration, immigration, Republic of Macedonia

\section{INTRODUCTION}

Movement from one area to another is typical of the human being as an individual and as a social being. In fact, "the history of humankind is a history of migration" (Böhning, 1978). Reasons, motives, directions, dynamics, ways of migration, etc. have evolved over time. The migrant is always confronted with a big challenge from the unknown, led by an ambition for a better life.

The territory of the Republic of Macedonia has always been a dynamic zone for migrations. Such an epithet is due to its geographical position as well as regional and strategic features, which were a sufficient reason for the country to be interesting to different conquerors. Waves of migration to and from Macedonia have taken place together with historical events and the geopolitical changes of the territory.

The oldest Macedonian settlers were the Neolithic tribes that lived in the region before 4,500 years BC (Stojimilov, 2005). At the beginning of the Metal Age, the ancient Macedonians came to these areas as part of the earliest Indo-European migrations. In the 580s and the 620s, the most intensive Slavic colonisation took place in the region of Macedonia. 
In the distant past, the territory of modern Macedonia was under the Byzantine, Serbian, Bulgarian and Turkish authority. After five centuries under Turkish authority, by virtue of the Treaty of Bucharest, the territory of ethnic Macedonia was divided among the winners of the Balkan Wars. In 1944, the Vardar part of Macedonia became part of former Yugoslavia as a Republic. In 1991, following a referendum, it became an independent country.

In the period after gaining independence, the existing socio-economic events have had significant influence on the dynamics of migrations in and out of the country. The transition process has had a particular impact, as well as the fragile economy, which had its recovery period resulting from the interruption or the reshaping of the economic relations with the countries of the former Yugoslavia (Madjevikj et al., 2016). Certainly, the 1999 events in Kosovo left their mark, as well as the war conflict in Macedonia in 2001. During the whole period of the 21st century, Macedonian citizens continue migrating out of their country. This migration stream, called "the modern migration" towards the developed countries, absorbing the young, reproductive and, above all, educated population, has caused a long-term damage to the demographic picture of Macedonia.

This paper has a review character and aims to contribute to the sublimation of the findings on the spatial and temporal dimensions of migration towards and from Macedonia, whose development can be linked to a number of spatial, economic, social, ethnic and cultural modifications of the territory of contemporary Macedonian society.

\section{RESEARCH METHODOLOGY AND DATA SOURCES}

Migration processes are analised in a chronological way, except in situations where this is impossible due to the time sequence of the events. The historically documented archival sources and published sources of data are taken as the most credible proof of constant migration flows in and out of the territory of the contemporary Republic of Macedonia. The data on international migrations are very scarce and incomplete, which completely hampers the research.

In this paper, we used the data from statistical and administrative sources, namely the population census data from 1953, 1961, 1971, 1981, 1994 and 2002. In terms of census methodology, there have been certain changes in reffering to the persons from abroad when defining the total population. Until the census of 1981, the total population of the Republic of Macedo- 
nia had included all persons with permanent residence in the Republic of Macedonia, regardless of whether and for how long they had been abroad at the moment of the census. In the censuses of 1994 and 2002, the persons who had been staying abroad for up to one year were included in the count of the total population.

Data on migration flows cover the number of citizens of the Republic of Macedonia and foreigners entering or leaving the Republic of Macedonia during one calendar year. These numbers have been obtained from the relevant services of the Ministry of Interior. They are published by the State Bureau of Statistics in regular, annual statistical reviews. The time series for the citizens of the Republic of Macedonia marks its beginning in 1992, and for foreigners in 1994. Due to compatibility of the data, we have started the analyses with a time series beginning from 1994.

Although census data are the most reliable data on migrations, providing a basis for tracing the number and characteristics of the migrant population, they do not fully represent the migration contingent. On the other hand, the Ministry of Interior data do not represent the entire picture of migration flows. The records of Macedonian citizens abroad can be obtained in the data sources of foreign international institutions and of the countries of reception, although there are some difficulties too.

Estimates are made and information regarding the total number of migrants based on citizenship or country of origin is taken from foreign sources held by the World Bank, Eurostat, OECD, IOM as well as from the official statistical data of the countries where citizens of the Republic of Macedonia live. Difficulties in gathering the exact data exist also because of differences among census questionnaires. Thus, in certain countries, the census questionnaire contains a question relating to the country of origin, while in other countries the questionnaire looks for an answer regarding the origin or the ethnic background. That way, the respondents give answers based on their ethnic background, and not their country of birth (Van Selm, 2007).

For the purposes of this paper, 30 interviews were conducted with Macedonian citizens who emigrated abroad. The interviews were conducted in the period September - December, 2017. The questionnaire consists of 10 questions of open and closed type (alternative questions and scaled ones). In the interviews, the respondents answered the questions relating to: motive for emigration, opportunity to come back to their country of origin, quality of life abroad, standards of living and integration in the new area. The interviewed males and females were aged between 20 and 45, having completed secondary or higher education. The respondents come from 
countries where the majority of the Macedonian citizens reside: Germany, Switzerland, Italy and Australia.

We also used the data of the International Organization for Migration (IOM) and those obtained from a poll conducted on a sample of transit migrants in Macedonia from August 2015 to February 2016, when Macedonia announced the refugee crisis (19 ${ }^{\text {th }}$ August 2015).

The analysis regarding the foreigners' stay in Macedonia and the recorded work permits, especially in the period from 2006 to 2015, was made according to the data from the Agency for Employment of the Republic of Macedonia.

\section{HISTORICAL AND GEOGRAPHICAL OVERVIEW OF MIGRATION IN MACEDONIA UNTIL ITS INDEPENDENCE}

\subsection{Immigration to Macedonia}

In the past, the first big wave of immigration to Macedonia was the arrival of the Slavs between the 580s and the 620s. During the 11th century, the Normans, Scythians, Pechenegs, Crusaders, etc., occupied the territory of Macedonia. Between 1045 and 1053, a certain number of Pechenegs settled in Ovche Pole. In the 12th century, the Kumanovo area became inhabited by the Cumans. The Saxons immigrated in the 13th century. Most of them settled in the Osogovo area where they started to develop the mining activities.

Big migration flows occurred after the fall of Macedonia under the Ottoman rule. In order to create support for the new political and social order in the conquered Macedonia, they brought in Turkish settlers. The most appropriate for settlement in Macedonia were the Anatolian nomads - Yörüks and Koniars. They came to Macedonia from Asia Minor at the end of the 15th and during the 16th century and inhabited the western parts of the Plačkovica mountain, Ovche Pole, the Tikvesh region, the area nearby Valandovo, etc. (Stojanovski et al., 1988). Forming the Yörük settlements, they had a purpose to gain control of the roads (Taševa, 1997).

The 16th century was marked by another wave of migration to Macedonia, this time led by the Roma, even though their presence on the Balkan Peninsula was recorded before the migration waves during the Ottoman rule (Stojanovski et al., 1988).

The ethnic mosaic was significantly enriched by the Jews escaping from the Inquisition, which was raging in Spain and Portugal at the end of the 
15th century. The Jewish colonies were created in all significant city centres in Macedonia.

More intensive immigration of the Albanian population in the territory of Macedonia began at the end of the 17th century and lasted during the whole 18th century (Kiselinovski and Stawowy-Kawka, 2004). At first, during the immigration caused by the Austrian-Turkish wars of 1683-1699 when they took over the places of the Macedonian population which emigrated in fear of retaliation by the Ottoman Empire army after the stifled Karposh rebellion (1689). During the 18th century, after the forming of an alliance between Austria and Russia, the Turks started to change the ethnic structure of whole regions as a reaction to these agreements. For this purpose, three processes started: Turkish colonization, Islamization of Slavs, and colonization of Muslim Albanians in the territory of Western Macedonia.

The peak of that colonization was reached in the period between 1780 and 1840 (Trifunoski, 1988). According to the same author, in the first period of this colonization wave, that took place from 1760 to 1800 , about $30 \%$ of Albanians that had lived in Macedonia immigrated. The immigration reached its peak between 1801 and 1840, when 50\% of Albanians immigrated. In the next wave that lasted until the fall of the Ottoman Empire, the immigration included only $10 \%$ of the current Albanian population. In the period from 1780 to 1800 they mainly immigrated to the areas near Gostivar, Kichevo, Tetovo, Skopje, Bitola and Prilep. From the beginning of the 19th century until the end of the fourth decade of that century, the Albanian population settled in about thirty other Macedonian villages (Konstantinov, 1992).

In the second half of the 18th century, when the town of Moskopole in Albania was ruined, a great number of the Vlach population immigrated to Macedonia, mostly to Bitola and its surroundings, then Krushevo, Ohrid, Veles and other towns.

In the 1860s, after the Crimean War, a significant number of Tatars and Circassians inhabited across the whole country. The settlement of Circassians in the Macedonian territory took place as a result of the Circassian colonization of the Ottoman state and of their expulsion from Serbia and Bulgaria (Pandevska, 1993).

In the second half of the 19th century, more precisely after the RussianTurkish war in 1878, a great number of the Muslim population called the Muhacir inhabited Macedonia, arriving from the territory lost by the Ottoman Empire (Taševa, 1997) together with the Turks-returners (Pandevska, 1993). 
Numerous Christian population of migrants with origins from Albania are recorded in many parts of Western Macedonia (Trifunoski, 1963), and that is in the area of Mijaks (Smiljanić, 1925), Poreche (Jovanović, 1935), Kichevo (Smiljanić, 1935), Debar surroundings (Filipović, 1939), Struga surroundings (Rusić, 1953), Skopje basin (Trifunoski, 1955), Tikvesh (Radovanović, 1924), and the Bitola-Prilep basin, arriving between the end of the 18th and the middle of the 20th century. They came from the surroundings of Korce, the south-west of Prespa, Golo Brdo, Girokaster, and Beratand in the Albanian coast (Trifunoski, 1963).

From the end of the 19th century to the 1920s, a part of colonization of the Serbian population took place on the territory of present-day Macedonia (which was part of the Kingdom of Serbs, Croats and Slovenians (SCS), or the Kingdom of Yugoslavia). They mostly inhabited the areas of Kumanovo, Skopje, Tikvesh, i.e. the Povardarje region, Ovche Pole and Pelagonija. According to Kiselinovski (2000), and the interpreted results of the 1931 census, in the period between the two world wars, the Kingdom of SCS colonized 96,347 people, or $10 \%$ of the population that lived on the territory of Vardar Macedonia in that period.

After the end of World War I, the Kingdom of SCS made a decision to accept Russian refugees. This immigration took place from the spring of 1919 until the autumn of 1921. In the analysed period, over 21,723 refugees passed through the shelter in Gevgelija (The State Archives of the Republic of Macedonia, f. 885), (Kovačeski and Dimitrijevski, 2012). Until 1941, 2,000-2,500 Russians had lived in the Macedonian territory. Most of them were highly educated intellectuals. In the new surroundings, they enabled the establishing of the basis of numerous economic branches and cultural activities in Macedonia.

In the period between the two world wars, especially since the liberation onwards, the fourth migration stream of the Albanian population was pointed towards Macedonia, but now from Kosovo. Mass immigration of Albanians from Kosovo was also noticed in the period from 1952 to 1970 (Svetieva, 2009), as well as later.

After World War II, people who declared themselves as Bosniaks moved to Macedonia from the former Sandžak and Bosnia and Herzegovina. They founded three big oases in Skopje and its surrounding area, in the surrounding area of Veles and in the surrounding area of Prilep (Trifunoski, 1956). Namely, with the emigration of the Turks and Muslims that declared themselves as Turks, there appeared conditions for the immigration of this population to Macedonia, which started in 1953 (Trifunoski, 1956). The low 
price of the land sold by the Turks who were leaving was also a benefit. Therefore, this migration was primarily recorded with the arrival of the population from the mountainous areas of Sandžak into the fertile Macedonian basins, which had remained empty after the Turkish emigration. As Turks, they had a right to move to Turkey, where they had relatives who emigrated in the 1922-1928 period. The immigration to Macedonia started in 1953, and the largest number of households settled in the period between 1954 and 1957, which is parallel with the largest post-war emigration of the Turks from 1954 to 1957.

"One of the consequences of the migration of ethnic Turks, the Torbesh and other Muslims from Macedonia, 127,000 people in total, was the important number of 20,440 people - migrants from Kosovo, Sandžak, Bosnia and Herzegovina, Montenegro and Southern Serbia, of which many have given up their journey to Turkey and stayed in Macedonian villages and cities. From the total of 20,440 Muslims from other republics and regions of the Federative People's Republic of Yugoslavia, the majority were ethnic Albanians $(10,643)$ and Bosnians from Sandžak $(5,276)$ "' (Ilievski, 2007; Todorovski, 1997).

It is essential to note the immigration after the civil war in Greece in 1948. There was massive emigration of the Macedonian population from the Aegean part of ethnic Macedonia. Therefore, about 50,000 Macedonians moved to the eastern European countries and to Yugoslavia (Pejov, 1968), while about 14,000 moved to the Republic of Macedonia.

\subsection{Emigration}

Although emigration flows were noticed much earlier, there is no documented record for this kind of migration. Therefore, the first emigration flows from Macedonia are considered the migrations to Italy, beginning from the second half of the 15th century.

More significant emigration took place in 1689 during the Austro-Turkish war and the famous Karposh uprising. After the Austrian army's retreat and the crushing of the Karposh uprising, the Ottomans started exacting revenge on the ethnic Macedonians. That was a cause of massive emigration of the Macedonian population towards the north, behind the Sava and the Danube. This emigration involved a larger group of Slavs in the Balkan region, and is known in history as "the Great Migration", during which a large part of the population of Skopje, Kumanovo, Polog, Veles, Shtip, Koani and Bitola emigrated (Zdraveva, 1997). Part of the population remained 
in Šumadija and the rest crossed the Sava and the Danube, spread through the Pannonian plain and came to northern Hungary.

After almost 190 years, still within the Ottoman Empire, the intentions of the Macedonian people to protect themselves from the reprisals were a reason for emigration abroad. More precisely, as a consequence of the Kumanovo-Kriva Palanka uprising crush in 1878, the population migrated from the other areas towards the liberated parts of the Serbian principality (Pandevska, 1993). During the 19th century, migration was mainly of economic and political nature. The poorly developed economy, high birth rate and labor surplus, together with the difficult living conditions of the Macedonian population, caused mass migration within the Ottoman Empire or abroad (Konstantinov, 1964). It was a time when the economic migration became intense.

Due to the large volume of total emigration from ethnic Macedonia, especially to the overseas countries, it is difficult to distinguish the citizens of the Republic of Macedonia (Janeska, 2001). Therefore, emigration that occurred from the middle of the 19th century to the division of the ethnic territory of Macedonia in 1913 is considered within the ethnic borders. It is estimated that during this period, between 70,000 and 100,000 people were emigrating from Macedonia every year. At the end of the 19th century, the first who crossed the sea were the people from southern and western Macedonia (Cvijić, 1922).

After the Ilinden uprising was crushed in 1903, part of the population "searching for food and safety", emigrated to Greece, Romania, Serbia, Bulgaria, other parts of the Ottoman Empire, towards Austro-Hungary and other countries in Western Europe. There are difficulties in estimating the number of Macedonians who were part of permanent and seasonal migrations at the end of the 19th and at the beginning of the 20th century within the Balkans. This particularly applies to migration to Serbia and Bulgaria, attractive destinations for the Macedonians after the Ottoman rule was thrown down. Svetieva (2002), stated that "immigrants in Serbia were registered under different names: Turks, Arbanas, Bulgarians Shopi, Debralii, Cincari, Gogi, Serbian (South Serbians), Chokalii etc." At the same time, their surnames were modified by adding the suffix -ić. The situation was similar in Bulgaria where they were registered as Bulgarians, or as Arbanasi. Determining the exact number of Macedonian emigrants is also difficult due to the specific political developments in the area of ethnic Macedonia. Until the division of the territory of ethnic Macedonia, the Macedonians 
traveled with Turkish travel documents, and later, they could pass the border with a Serbian, Bulgarian or Yugoslav travel document. In the countries where they immigrated, their nationality was determined according to the travel document, due to the fact that it was the only document they had.

According to some authors, about 30,000 emigrants from Macedonia went to Sofia, as well as to the USA, Canada and Australia, (Gaber and Joveska, 2004; Van Selm, 2007). Seven to eight thousand people immigrated to North America (Stojanovski et al., 1988). In Canada, the Macedonian immigration during this period occurred mainly because of political reasons. During the same time period, those immigrating to Australia were mainly economic migrants. The earliest migrants in the late years of the 19th century were searching for gold (Van Selm, 2007). According to other original data in the period between 1903 and 1906, about 50,000 people moved to America, out of which 18,000 stayed there permanently (Andonov, 1973, 1978).

Large emigration occurred during the Balkan wars and World War I. Therefore, after Balkan War I, together with the retreat of the Turkish army, a significant number of the Turkish population migrated to Turkey. That was the reason for the Turkish population in Macedonia to decrease by 56,000 people in the period between 1900 and 1921. Their emigration continued with the conclusion of an agreement between the Kingdom of Yugoslavia and Turkey (1933), referring to the emigration of ethnic Turks and other so-called Turks, i.e. Muslims from the "Southern Serbia or Vardar Macedonia" territory (Öksüz and Köksal, 2004). In the period after World War II the emigration of this population continued on the basis of the agreement between Yugoslavia and Turkey signed in 1952, where FPR Macedonia had the role of a transit centre. Even though the strongest emigration wave took place between 1954 and 1957, emigration also intensified after 1958 (Svetieva, 2009). Then, from 1953 to 1981 the number of the Turks decreased from 203,938 to 86,591, i.e. approximately 117,000 Turks emigrated from the Republic of Macedonia. Together with the Turks, other Muslim populations emigrated as well, especially the Macedonian Muslims.

The emigration from Macedonia to the other republics in Yugoslavia in the post-war period was always larger than the immigration. According to the census of 1961, the difference between the emigrants and immigrants was 4,828, and in 1971 it amounted to 6,205 people. The largest number of Macedonian emigrants moved to Serbia - about $80 \%$, then Croatia, Bosnia and Herzegovina, etc. After World War II, Vojvodina region in Serbia was inhabited by agricultural colonists from the former Yugoslavia, including 
the Macedonians. About 2,000 families emigrated from the areas of Kriva Palanka, Kumanovo and Poreche, and a little less from the areas of Struga, Demir Hisar, Ohrid, Veles, Skopska Crna Gora etc. (Trifunoski, 1958). Even at the beginning it was planned for the population to inhabit four villages: Jabuka, Kacarevo, Glogol and Knichkanin. Later they also inhabited seven villages in the area of Vršac. The immigration took place from January until July 1946 (Kicošev, 1996). Until 1948, 9,975 people emigrated from Macedonia to Vojvodina (Banat, 9,093; Bačka, 713; Srem, 169) (Đurđev, 1995).

The following emigration flows from Macedonia, especially in the 1960s and 1970s, were caused by the world economic climate. Although there has been a tendency to free the flows of good sand capital at the global level, there has been no parallel trend to free the flows of the people. Yet, beginning in the 1960s, several countries of immigration liberalized their admission policies, thus allowing the immigration of persons from a greater variety of countries (Zlotnik, 1999). For example, in the 1960s, West Germany started promoting temporary immigration for young workers ("gastarbeiters"), intergovernmental agreements with other Western European countries, as well as with Turkey, Morocco, Tunisia and the former Yugoslavia (Stalker, 2002). From the liberation until 1960, the number of people who emigrated from Macedonia was small.

The small number of emigrants until the sixties was the result of the existing policy in the former Yugoslavia. In fact, up to the 1960s of the last century, socialist society was characterized by closeness and a negative political attitude towards emigration abroad (Janeska, 2001), with the excuse that in Yugoslavia there were employment opportunities for every citizen, and emigration was seen as a negative and unacceptable event. Therefore, economic emigration was almost excluded, and political emigration was more common. At the beginning of the 1960s, along with the changes in the political attitude towards emigration abroad, the migration wave from Yugoslavia, including Macedonia, increased, especially since 1964. In the period from 1961 to 1975 there was significant economic emigration, temporary employment abroad and permanent emigration to overseas countries (Nikolovski, 2010).

The most intensive emigration was recorded from 1971 to 1974, in a period when there were favourable conditions in the labour force market in the developed Western European countries (Dimitrieva and Janeska, 1985). According to the census of 1981, there were 100,919 people abroad. The emigration rate from Bitola, Resen and Demir Hisar was over $30 \%$, and "the number of employed people from Resen abroad was bigger than the 
number of employed people in the municipality" (Bogoev, 1985). It was also obvious that in the subsequent period they kept the emigration image. The problem was that many other municipalities, especially from the eastern part of Macedonia, followed their example. The period between 1976 and 1990 saw the decreasing number of employments abroad, returning of the emigrants, uniting of the remaining families, gradual transformation of the temporary to permanent stay (Bornarova and Janeska, 2012). At the end of the 1980s, emigration intensified again. After 1990, the largest emigration wave from the Republic of Macedonia was recorded as permanent family emigration and the uniting of families (Risteski, 2013).

\section{INTERNATIONAL MIGRATION AFTER MACEDONIA'S INDEPENDENCE}

\section{1. Immigration}

After the Republic of Macedonia became independent, mainly due to the unfavorable political circumstances and military tensions in the Balkans, citizens and foreigners from the former Yugoslav republics began immigrating. Based on the migration flows in the period from 1994 to 1999, it is evident that on average, $91 \%$ of the citizens immigrating to the Republic of Macedonia were from the former Yugoslav republics, mostly from SR Yugoslavia, Croatia and Bosnia and Herzegovina. During the same period, two thirds of the immigrants were from the former Yugoslav republics, that is from the FR Yugoslavia and Bosnia and Herzegovina.

Immigration flows of people with foreign citizenship originating from the former Yugoslavia continued towards Macedonia also in the period from 2000 to 2015. They mainly arrived from Kosovo, as part of the fourth immigration wave of the Albanian population. ${ }^{1}$ Apart from Kosovo, the most numerous were the immigrants from Albania and Turkey, as well as from Montenegro and Bosnia and Herzegovina. Only a small proportion of immigrants from Albania were of Macedonian nationality, mainly from the region of Mala Prespa in Albania.

Dukadin, Shkumbin and Tuscan migration streams were the first three streams of emigration of Albanian population to Macedonia. 
Figure 1. Immigration flows of the total population, citizens of the Republic of Macedonia and foreigners in the 1994-2015 period

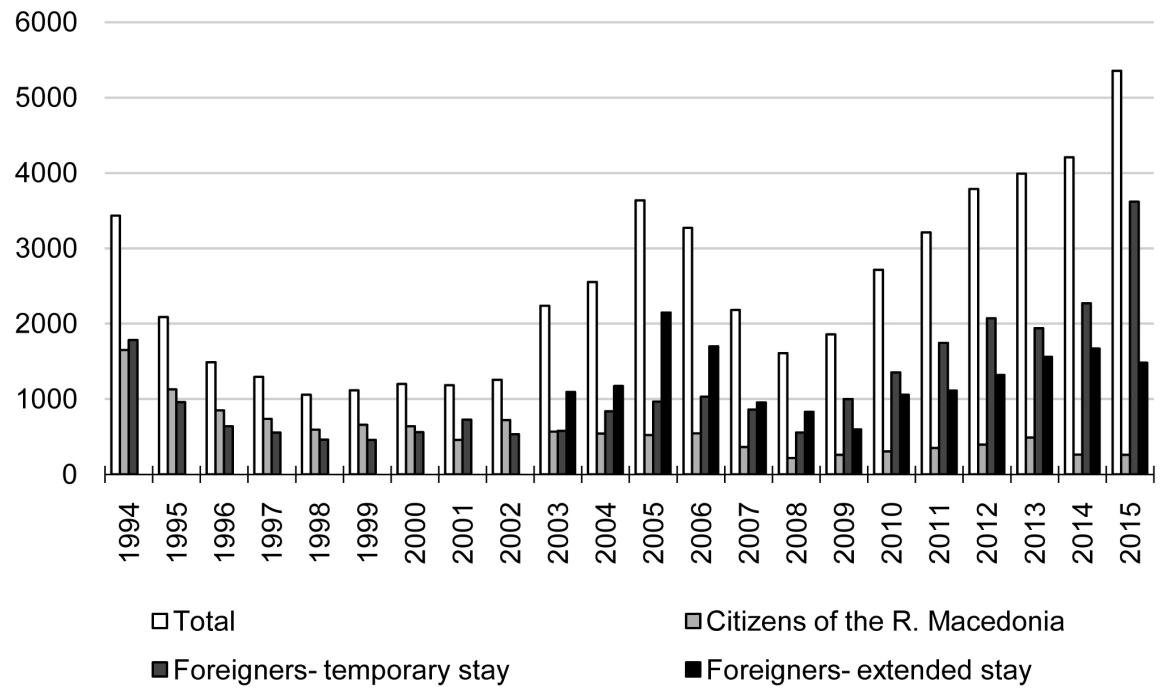

Source: SSORM, Population and social statistics, Migration 1994-2015, SSORM.

Until 2003, the positive total net migration had been a result of the positive net migration among both the citizens of the Republic of Macedonia and foreigners. Since 2004, the positive net migration has been caused by the positive net migration of foreign immigrants.

The reasons for the immigration of foreigners are various, but are related to the smaller spatial distance, ethnic affiliations, employment opportunities or the development of their own business, marriage, education, etc. Since 1992, the immigration of young girls from Albania in order to marry Macedonian citizens is a regular occurrence (Government of the Republic of Macedonia, Strategy for the Integration of Foreigners and Refugees in the Republic of Macedonia, 2008-2015). Also, many foreign students are enrolled in Macedonian universities. Prior to Macedonian independence, there were students from African and Asian countries. Their numbers dropped significantly after 1991. From the academic year 2007/08 to 2015/16, a total of 14,655 foreign students enrolled in the undergraduate studies. Nearly $1 / 3$ was from Serbia, $21.5 \%$ were from Kosovo and $44 \%$ were from Turkey. 
Figure 2. Net migration of migration flows of the total population, citizens of the Republic of Macedonia and foreigners in the 1994 -2015 period

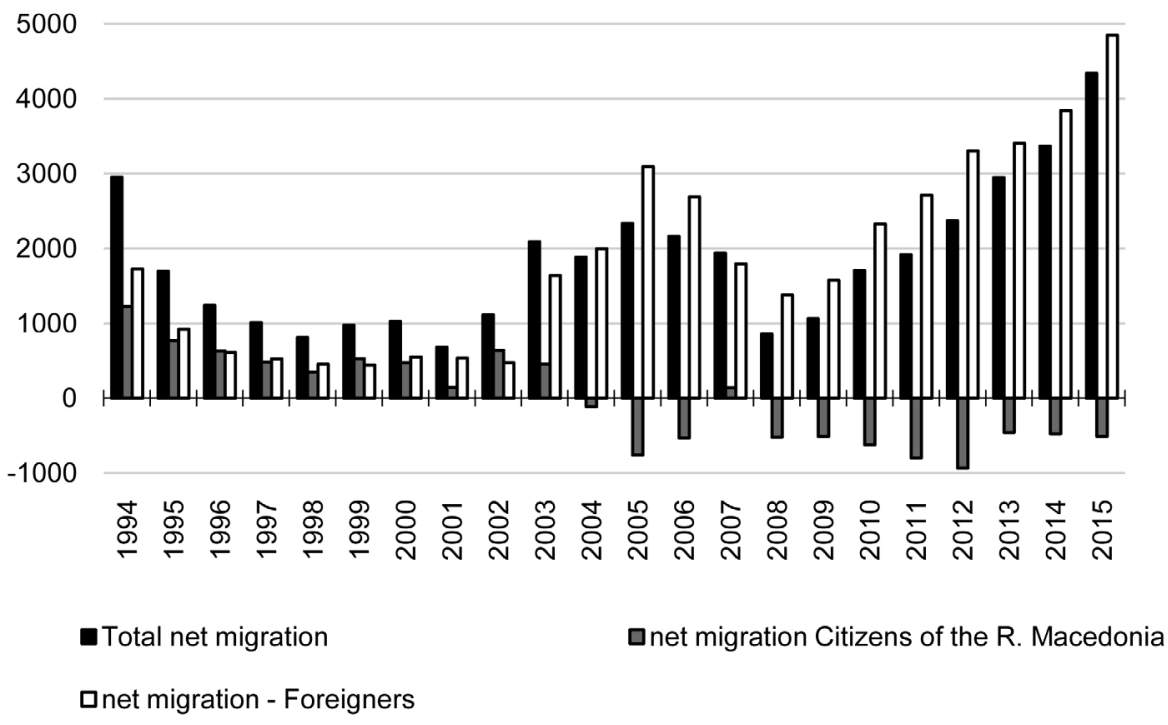

Source: SSORM, Population and social statistics, Migration 1994-2015, SSORM.

The immigration of foreign citizens to Macedonia, especially those of Albanian nationality, is certainly stimulated by the political intentions of ethnic reshaping of the area. It would further fit into the future plans of the creators of such policies.

Between 2006 and 2015, approximately 3,000 work permits were issued for foreign citizens, i.e. employment permits, personal work permits and work permits (ESARM, 2017). Most of the foreigners were from Greece, Turkey, Serbia, Albania and Kosovo, as well as from Germany, Russia, etc. The largest numbers of work permits were issued for the purpose of employment in the city of Skopje. About a third of the foreigners who requested work permits had completed higher education, but there were a significant number of those who had finished secondary and primary education. Their work profiles were different, from qualified workers, bakers to managers. As a result of the FDI in Macedonia (Apostolovska Toshevska and Ljakoska, 2017), employment in new companies has certainly created opportunities for the immigration of individual foreigners, who were mostly part of the management team of investors. 
The Macedonian economy is benefiting from the immigration of foreign population with better material and financial basis, because it stimulates the economy, in spite of the effect of low-income foreigners, whose salaries are mainly returned to their families and make foreign currency exports. Special attention should be paid to foreigners who have short-term investments that can cause economic damage to the country (Nikolovski, 2010).

According to the IOM and Eurostat; in 2015, 130,730 immigrants lived in Macedonia. They represent $6.29 \%$ of the overall population of the country. From the total number of immigrants, $51.8 \%$ are from Albania $(67,799)$ and together with the foreigners from Turkey $(19,922)$ and Serbia $(17,930)$, constitute $80.8 \%$ of the total number of foreigners in Macedonia.

After 2000, the intensity of immigrant flows of Macedonian citizens has decreased. The immigration mostly occurs for family reasons or marriage. More than a third of the immigrants have finished primary education (35.3\%), while $43.7 \%$ have finished secondary education. About $45 \%$ of them are employed, and one fifth are economically supported. About 95\% come from the European continent. They are mostly people from the Macedonian or Albanian ethnic community. From the total number of immigrants, $85 \%$ are between 20 and 64 years old, $36 \%$ are between 40 and 60 , and one fourth between 50 and 64 . In the analysed period, about $12 \%$ of the immigrants are pensioners.

\subsection{Emigration}

After becoming independent, the Republic of Macedonia faced some serious economic problems. Having a dependent economy and major export and production connections to the north and the rest of the Yugoslav republics, the functioning of the manufacturing facilities that were mainly tailored to the needs of Yugoslavia became more difficult. Apart from the confusing economy, the Greek embargo followed in 1994. Given these reasons, as well as many others that followed, many citizens emigrated. The conditions did not change in the following years. Macedonia entered the new millennium with social problems, ethnic tensions and economic instability. The conflict in 2001 resulted in a shaken confidence on ethnic grounds and caused a deeper ethnic tension that again led to economic instability. With a rate of unemployment of 32\% in 2010, the Republic of Macedonia had almost four times the unemployment rate of the EU countries (Apostolovska Toshevska et al., 2012), but also a higher unemployment rate compared to its neighbours Serbia (20\%), Croatia (11.8\%), Slovenia (7.2\%) (Report on the development of Serbia, 2011). The citizens of the Republic of Macedonia 
saw migration as a powerful strategy to overcome difficulties and ensure a better life. Therefore, in this period, the young people's ambitions for leaving the country and going to some of the European or overseas countries increased. Witnessing a gradual transformation of social values and ideals, the population faced the disrespect of labour and its low value as well limited opportunities for professional advancement.

During the interview, when asked the question: Why did you leave Macedonia?, most of the respondents emphasized that this was due to the fact that their labor was not valued enough in the Macedonian society and because of the disrupted value system, emphasized partisanism, absence of democracy, low quality of life and persistent ethnic and political tensions.

When asked if their expectations for living abroad were fulfilled: over $2 / 3$ of the respondents said they were relatively satisfied, and the rest said that they were satisfied. Only two of the respondents said that they would like to return to Macedonia if the situation improved on an economic and political basis for real. Even though the way of life is not what they imagined to be like, the ambition for higher earnings and the opportunities offered are sufficient motives to be persistent. Some respondents claimed: "roses are not blooming abroad as one may expect before emigration". Despite the difficulties, emigrants rarely stated that they would return even if they earned enough money in their own country or as they said: "You get into the dynamics of society, you become part of the mechanism, you work and you earn. You earn enough to pay the bills. You have a safe future". In fact, everything is about the symbolism of "safe future", which, if questionable (in terms of security and economy), is something that perhaps mostly influences the young people to leave the country.

The abolition of visas had additional impact in 2009. That was a reason for the increased number of emigrants to the countries of the EU. But here, one should not ignore the frequent applications of potential emigrants for acquiring Bulgarian passports, after Bulgaria became a member of the EU. The practice was publicly advertised in the media, and individuals developed businesses for mediation in the procedure for obtaining a Bulgarian passport. The interested users were motivated by the practical and economic benefits of possessing a Bulgarian passport, and as Neofotistos (2014) noted, a "Bulgarian passport has a role of a fetish object for certain citizens" of the Republic of Macedonia, not paying attention to the repercussions that could follow.

Acording to the records of emigrants from Macedonia in the 2000-2015 period, $90.1 \%$ were citizens of the Republic of Macedonia. The average age 
of the people who emigrated was 38 years. $2 / 3$ of the emigrants were between 15 and 49 years old and 1/3 were between 20 and 34. In fact, on average, the emigrants are younger than the overall population of the country. Beginning with the fact that those are the people whose age is most suitable for biological reproduction, a conclusion could be drawn that Macedonia irretrievably loses young, working age population, which will negatively affect the demographic structures. Also, about $54 \%$ of the women included in the emigration flows in that period were in their optimal reproductive period, (20-34 years old). However, that particular young population is ready to face the uncertainty of migration and the challenge to build a future in another country.

A better circumstance is having a suitable education which ensures a better quality of life. The migration of educated people means a big loss for the country. On the other hand, the benefits for Macedonia from the inflows of bank remittances from the emigrants abroad are high. During the period from 2000 to 2005, on average, they accounted for $8.2 \%$ of the exports, $5.1 \%$ of the imports and $2.6 \%$ of the GDP (Nacevska et al., 2008). "...remittances inflows to Macedonia have been growing steadily in the period 2003-2010 (from 115.2 million EUR in 2003 to 181.8 million EUR in 2010). After a slight decline in 2011 and 2013, they continued to grow and hit the record of 194.5 million EUR in 2015" (Bucevska, 2016). They are a significant source of incomes for a part of the Macedonian households.

Almost 2/3 of the emigration flows are directed towards some of the European countries (Germany, Switzerland, Italy and other), out of which $12.1 \%$ towards America and almost 10\% towards Australia and Oceania.

Despite the previously mentioned developed countries, particularly interesting is the fact that many Macedonians are leaving to work in high-risk military countries such as Afghanistan. Most of them are from Kumanovo and Tetovo. There is no accurate record for the number of these workers, although there are several firms that recruit workers in these areas, such as: FLOUR, DajnCorp, ITT Systems and Ecologist. According to the CEA study (2008), the company FLOUR alone sent over 1,400 workers from Macedonia. According to the same study of 2008, the Polog region participated with $32.5 \%$ and the Kumanovo region with $6 \%$ of the total remittances sent from Macedonia.

Apart from this trend for permanent emigration, many young people, mainly students, go to work abroad for a limited period of time through employment agencies or students' "work and travel" and "internship" programs. Most of them work in Germany, Italy, Austria, Sweden, the USA, 
Canada and Australia. In the absence of a legal obligation for the mediation agencies to submit data on the number of persons involved in their programs for the bureau of statistics, there are no specific data on the exact number of this type of emigrants.

Only the Kouzon Corporation provides between 800 and 1,500 jobs for students in the United States annually (www.kouzon.mk). Part of them uses it as a preparation for permanent emigration.

The precise number of Macedonian citizens abroad is difficult to determine. Prior to 1990, by travelling with a Yugoslav passport, citizens of the Republic of Macedonia were registered as Yugoslavs in the reception countries. In recent decades, a relatively small number of emigrated Macedonian citizens have registered abroad properly. Also, part of the Macedonian population, especially in the EU countries, obtains a Bulgarian passport for easier access, so these citizens are registered as Bulgarian citizens in the countries of reception.

According to the census of 1994, the number of Macedonian citizens staying abroad for more than a year amounted to 173,611 , i.e. three times the number recorded in 1961. In the total number, data for the citizens of Macedonia in all the countries in which they lived are omitted, and data from the former Yugoslav republics are also missing. Therefore, it can be concluded that the number of Macedonian citizens abroad in 1994 was significantly higher. In the next census conducted in 2002, a total of 22,995 people were recorded as staying abroad up to one year and another 12,128 staying longer (Markiewicz, 2006).

The calculations show that between 350,000 and 2 million Macedonian citizens live around the world (Van Selm, 2007). Based on the country of origin from the migrant stock data, the World Bank estimates that 626,312 Macedonian citizens had emigrated until the end of 2013 (World Bank, 2014). That is about $30 \%$ of the whole population of the country. According to the OECD data (2015), the number of Macedonian citizens all around the world was 284,285 in 2015. However, this figure does not include the data on the number of emigrated Macedonian citizens in many overseas countries. The Macedonians that are not citizens of the Republic of Macedonia, and live in Bulgaria and Albania, are also a problem (Markiewicz, 2006), as well as those living in most of the former Yugoslav republics.

Based on the Eurostat data (2014), in the European countries alone, the number of Macedonian citizens increased from 135,000 in 2000 to 240,000 in 2014. "The largest increase is noticed in the receiving countries of the European Union, especially in 2011, after the stagnation during the eco- 
nomic and financial crisis (2008-2010). These trends correspond with the changes in the migration policies of the receiving countries" (Janeska et al., 2016). According to the IOM, 516,024 Macedonian citizens lived outside the country in 2015 , i.e., $19.89 \%$ of Macedonian population. They were mostly in Germany (around 64,000), then Italy and Switzerland, as well as Sweden, Austria, France, Holland and other European countries. There are about 18,000 in the Scandinavian countries. According to the IOM data, 79,398 Macedonian citizens live in the former Yugoslav republics, out of which 46,737 or 59\% live in Serbia, 16,510 in Slovenia, 10,055 in Croatia and 3,317 in Montenegro.

The highest percentage of economic emigration is from Resen and Bitola, then from Demir Hisar, Ohrid, Kichevo, Struga, Gostivar, Tetovo as well as the municipalities from the eastern part of Macedonia.

\subsection{A brief overview of the refugee crises}

From the period after the independence until today, Macedonia has dealt with several refugee crises. The first occurred in 1991, as a result of the events in Albania. More specifically, in 1991 and 1992, when Albania faced a serious political crisis, the existing events caused serious problems for the population. For that reason, about 1,200 people from the border areas (Albanian and Macedonian population from the region of Mala Prespa in Albania) asked for protection in Macedonia and were admitted. Shelters were opened in the following cities: Resen, Ohrid and Struga. After overcoming the problems, a large part of these people returned to Albania, while one part, especially from the area of Mala Prespa, remained in the country (Strategy for Integration of Refugees and Foreigners in the Republic of Macedonia 2008-2015).

At the same time, that period marked the beginning of the crisis of the former Yugoslavia. In the wave of refugees fleeing the war developments, 35,000 refugees from Bosnia and Herzegovina were accepted. Refugees were accommodated in seven shelters and in households. They were taken care of by authorized institutions in Macedonia until 1997, i.e. the stabilization in Bosnia and Herzegovina when they were returned to their homes. In 1999, during the Kosovo crisis, about 360,000 people, mainly Albanians from Kosovo, asked for and received protection in Macedonia. Around 234,000 of them were accommodated in households, and 123,000 in eight reception centers. The largest reception center admitting 91,476 persons was in "Stenkovec" near Skopje. They were staying there for a few months. Some of them, like the Roma from Kosovo, stayed for many years. 
Macedonia was not bypassed by the biggest migration crisis that happened on the European continent after World War II. Since it is located on the Balkan migration route, on the way to the European countries, during 2014, 2015 and 2016, about one million refugees and migrants from Asia and Africa passed through Macedonia. According to the IOM data, only between August 2015 and February 2016, an average number of 8,200 migrants per day passed through Macedonia. About $60 \%$ of them were from Syria and the rest were from Afghanistan, Iraq, etc. For the migrants, Macedonia is not attractive as the ultimate destination, they are just transiting.

According to the Law on Asylum and Temporary Protection and its bylaws, (Official Gazette of the Republic of Macedonia, nos. 54/2013, 101/2015, $152 / 2015,55 / 2016$ and 71/2016) a foreigner on the border crossing or on the territory of the Republic of Macedonia can declare the intention to seek asylum either orally or in writing. The intention is registered by the police officer of the Ministry of Interior, and the foreigner must submit an asylum application to the Asylum Sector at the reception center for asylum seekers within 72 hours. In the period from 19 June 2015 until 31 December 2015, 388,233 asylum applications were submitted, of which 209,914 by men and 65,893 by women, 95,303 by children accompanied by their parents and 18,123 by unaccompanied minors (www.mvr.gov.mk/vest/1195). Most of the applicants were from Syria, Afghanistan, Iraq and Pakistan. Far fewer persons had applied for actual asylum in Macedonia. In 2014, 1,283 asylum applications were submitted, and in 2015, there were 1,896 (Macedonian Young Lawyers Association, 2016). During the asylum procedure, applicants are placed in an asylum-seeker reception centre in Vizbegovo under the authority of the Ministry of Labour and Social Policy.

Even though these migrations were transitive, they had economic, humanitarian and security consequences in the country. Macedonia refused the offer for building a refugee camp on its territory, which would additionally burden the functioning of the country. In the Macedonian shelters, up to 2,000 people could stay for a few hours and that is 1,500 in Gevgelija on the southern border and 500 people in the shelter in Tabanovce on the northern border. 


\section{CONCLUSION}

The geographical location, history, political, social and economic conditions were push and pull factors that defined the directions, intensity and flow of migration into and out of Macedonia from its first settlements until today. It is interesting that the conditions have changed, but Macedonia still "nurtures" the image of a migration country.

In the past, along with the geopolitical changes of the territory and government, colonization politics and immigration were implemented on the modern Macedonian territory. During the Ottoman Empire rule, the most intensive immigration to the Macedonian territory was noted. The period between the 15th and the end of the 19th century is especially emphasized, with the immigration of the Yörüks and Koniars, and later the Albanians. The main goal was to change the ethnic image of the area. On the other hand, it meant greater security for the then rule. The immigration of other nations continued.

After 1990 and the collapse of Yugoslavia, Macedonia recorded migration flows from the former Yugoslav republics, including both the citizens of the Republic of Macedonia and foreigners. Most of them came from FR Yugoslavia, as well as from Croatia and Bosnia and Herzegovina. During the subsequent period, there were regular immigration flows of foreigners, mostly from Albania, Kosovo and Turkey.

The first recorded emigration data were documented in the mid-15th century. However, emigration, especially economic, is typical for the population of Macedonia in the mid-19th century. More precisely, as a result of the difficult economic situation, migration became more intensive. People went to work abroad in the European cities, and by the end of the 19th century, they were going to the United States, Canada and Australia.

In the middle of the last century, the emigration of the Turkish population was massive. Macedonian Muslims and Bosniaks migrated along with the Turkish population. Considering that Macedonia was the starting point from where this population left for Turkey, one part of the Bosniaks remained in Macedonia.

In the recent history, emigration was less present until 1960, as a result of the closeness of socialist society and the negative attitude towards emigration abroad. In the 1960s, as a result of a change in the state policy regarding emigration abroad, the emigration wave intensified. The situation in the political orientation changed after 1964, which further intensified emigration. The largest emigration was recorded from 1971 to 1974, at the time 
when there were favourable conditions on the labour markets of developed western European countries. From 1976 to 1990 the most noticeable feature was reduced employment abroad, the return of the workers, the uniting of the families of those who stayed, transforming the temporary to permanent stay. At the end of the 1980s, emigration intensified again, and after 1990 the most intensive emigration wave has begun, and still lasts.

In the period after 1990, as a result of the current economic situation and the high unemployment rate, as well as of the persistent political and ethnic tensions, the emigration wave from Macedonia continued. This condition is worrisome and will have a long-term impact on the demographic picture of Macedonia. The average age of the emigrants is lower than the average age of the population in the country. At the same time, highly educated people emigrate, too. Easy access to information about open opportunities for a better life and employment, relief from prejudice in the new environment, as well as easier ways of travelling have allowed the realization of their ideas. To live according to modern criteria, in social surrounding that will not ruin the individual dignity, in a society where labour is appreciated together with knowledge and creativity is the main driving force for many emigrants.

There are difficulties in determining the exact number of Macedonian citizens in the world, primarily because of differing statistical approaches to population registration, the ineffectiveness of emigrants when registering in and checking out their stay, the acquisition of Bulgarian citizenship, etc.

The largest migration flows were directed towards the European countries, mostly Germany, Italy and Switzerland. The largest number of Macedonian citizens lives in these countries. In overseas countries, there is a large number of Macedonian citizens in Australia, the United States and Canada.

\section{REFERENCES}

Andonov, V. (1973). Makedoncite vo Avstralija. Skopje: Kultura.

Andonov V. (1978). Iseluvanjata od Makedonija, makedonskoto iseleništvo vo prekuokeanskite zemji i negovoto organizirano sobiranje, in: Iseljeništvo naroda $i$ narodnosti Jugoslavije $i$ njegove veze s domovinom. Zagreb: Zavod za migracije i narodnosti, 210-221.

Apostolovska Toshevska, B., Markoski, B., Dimitrovska, O., Milevski, I. and Gorin, S. (2012). Characteristics of the unemployment in the Republic of Macedonia, Human Geographies, 6 (1): 59-65, doi: http://dx.doi.org/10.5719/hgeo.2012.61.59 
Apostolovska Toshevska, B. and Ljakoska, M. (2017). Structural and spatial (re) organization of the industry in the Republic of Macedonia in the 21st century, in: Proceedings of the third international scientific conference Geobalcanica 2017, 20-21 May 2017, Skopje, Republic of Macedonia. Skopje: Geobalcanica Society, 271-278, http:// dx.doi.org/10.18509/GBP.2017.36

Bogoev, K. (1985). Osnovnite karakteristiki na demografskiot razvoj na SR Makedonija, in: Problemi na demografskiot razvoj vo SR Makedonija. Skopje: MANU, 7-29.

Böhning,W.R.(1978).InternationalMigrationand theWesternWorld:Past,Present, Future. International Migration, 16 (1): 11-22, doi: https://doi.org/10.1111/j.1468-2435.1978. tb00959.x

Bornarova S. and Janeska V. (2012). Social Impact of Emigration and Rural-Urban Migration in Central and Easter Europe: Final Report - European Commission. Gesellschaft für Versicherungswissenschaft und -gestaltung e.V.

Bucevska, V. (2016). Ciklični karakteristiki na doznakite: slučajot na Makedonija, Godišnik na Ekonomskiot Fakultet, 51: 65-74.

Center for Economic Analyzes - CEA. (2012). Study on the Significance of Private Transfers from Persons Working in Afghanistan and Iraq for Kumanovo and Tetovo.

Cvijić, J. (1922). Balkansko poluostrovo i južnoslovenske zemlje. Beograd: Državna Štamparija Kraljevine Srba, Hrvata i Slovenaca,

Dimitrieva, E., and Janeska, V. (1985). Osobenosti na migracionite dviženja od Socijalistička Republika Makedonija vo stranstvo, in: Problemi na demografskiot razvoj vo SR Makedonija. Skopje: Makedonska akademija na naukite i umetnostite, 337-354.

Direkcija za ekonomsko planiranje, Bosna i Hercegovina, Ekonomski trendovi, 2010.

Đurđev B. (1995). Posleratno naseljavanje Vojvodine. Metodi i rezultati demogeografske analize naseljavanja Vojvodine u periodu 1945-1981. Novi Sad: Matica srpska.

Filipović, M. (1939). Debarski Drimkol. Skopje: Štamparija “Južna Srbija”.

Foundation Open Society Macedonia (2016). Availability and access to free legal aid for persons seeking asylum in the Republic of Macedonia. Skopje: Macedonian Association of Young Lawyers.

Gaber, N. and Joveska, A. (2004). Macedonian census results - controversy or reality?, South-East Europe Review for Labour and Social Affairs, 1: 99-110.

Government of the Republic of Macedonia (2008). Strategy for the Integration of Refugees and Foreigners in the Republic of Macedonia 2008-2015. Skopje: Ministry of Labor and Social Policy.

Ilievski, B. (2007). Politički, ekonomski i prosvetni aspekti na iseluvanjeto na turskoto naselenie od Makedonija vo pedesetite godini na XX vek, Istorija, 1-2: 49-62.

Janeska, V. (2001). Sovremenite megjunarodni migracii, emigracijata od Republika Makedonija i socio-ekonomskiot razvoj. Skopje: Univerzitet “Sv. Kiril i Metodij”, Ekonomski institut.

Janeska, V., Lozanoska, A. and Djambaska, E. (2016). Demographic consequences of the emigration from the Republic of Macedonia, Economic Development, 18 (1-2): 157-178.

Jovanović, P. (1935). Poreče, Naselja i poreklo stanovništva, knj. 28, Srpski etnografski zbornik, 51: 243-335.

Kicošev, S. (1996). Brojnost i teritorijalni razmeštaj stanovništva u Vojvodini, in: Zbornik od proiot kongres na geografite od Republika Makedonija, 26.-28.10.1995, Ohrid. Skopje: Makedonsko geografsko društvo, 177-184. 
Kiselinovski, S. (2000). Etničkite promeni vo Makedonija: 1913-1995. Skopje: Institut za nacionalna istorija.

Kiselinovski, S. and Stawowy-Kawka, S. (2004). Malcinstvata na Balkanot (XX vek). Skopje: Institut za nacionalna istorija.

Konstantinov, H. D. (1964). Pečalbarstvo. Bitola: Naroden muzej.

Konstantinov, M. (1992). Makedonci. Skopje.

Kovačeski, S. and Dimitrijevski, M. (2012). Dr. Nikola and Sofija Nezlobinski. Struga: Iris Print.

Madjevikj, M., Apostolovska Toshevska, B., Gorin, S. and Ljakoska, M. (2016). The regional differentiation of the demographic movements in the Republic of Macedonia, Environmental \& Socio-economic Studies, 4 (3): 10-20.

Markiewicz, M. (2006). Migration and remittances in Macedonia. Skopje: Center for economic analyses.

Načevska, E., Krstevska, A., Petrovska, M. and Univeska, D. (2008). Analiza na privatnite transferi vo platniot bilans na Republika Makedonija. Skopje: NBRM.

Neofotistos, P. V. (2014). Bulgarian passports, Macedonian identity, looking for EU citizenship in the Republic of Macedonia, EthnoAnthropoZoom, 10: 36-54.

Nikolovski, Z. (2010). Migracii, kontraindikacii i prichina za pozitioni efekti. Skopje: Autoprint T. A.

Öksüz, H. and Ü. Köksal. (2004). Emigration from Yugoslavia to Turkey (1923-1960), Turkish Review of Balkan Studies, 9: 158-173.

Pandevska, M. (1993). Prisilni migracii vo Makedonija vo godinite na golemata istočna kriza (1875-1881). Skopje: Institut za nacionalna istorija.

Pejov, N. (1968). Makedoncite i Gragjanskata vojna vo Grcija. Skopje: Institut za nacionalna istorija.

Radovanović, V. (1924). Tikveš i Rajec, Naselja i poreklo stanovništva, knj. 17, Srpski etnografski zbornik, 29: 129-517.

Republic of Serbia, Ministry of Finance. (2011). Serbia Development Report 2010. Belgrade.

Risteski, S. (2013). Posledici i implikacii od nadvorešnite migracii vrz socio-ekonomskiot razvoj i demografskiot razvoj na Republika Makedonija, Godišnik na Ekonomskiot fakultet, 48C: 169-180.

Rusić, B. (1953). Malesija, Godišen zbornik na Filozofski Fakultet, 6: 1-64.

Smiljanić, T. (1925). Mijaci, Gornja Reka i Mavrovsko Polje, Naselja i poreklo stanovništva, knj. 20, Srpski etnografski zbornik, 35: 1-122.

Smiljanić, T. (1935). Kičevija, Naselja i poreklo stanovništva, knj. 28, Srpski etnografski zbornik, 51: 337-483.

Stalker, P. (2002). Migration Trends and Migration Policy in Europe, International Migration, 40 (5): 151-179, doi: https://doi.org/10.1111/1468-2435.00215

Stojanovski, A., Katardžiev, I., Zografski, D. and Apostolski, M. (1988). Istorija na makedonskiot narod. Skopje: Makedonska kniga.

Svetieva, A. (2002). Migration: Questions of Identity, EthnoAnthropoZoom, 2: 117-128.

Stojmilov A. (2005). Socioekonomska geografija na Republika Makedonija. Skopje: Prirodnomatematički fakultet, Univerzitet "Sv. Kiril i Metodij". 
Svetieva, A. (2009). On the migration of the Balkan Muslims and of the 'Nashinci': The Torbesh, Pomaks and other (Turks) in Turkey, EthnoAnthropoZoom, 6: 39-67.

Taševa, M. (1997). Etnički grupi vo Makedonija. Skopje: Istoriski kontekst.

Todorovski, G. (1997). Demografski procesi vo Makedonija predizvikani od razmestuvanjeto na Turcite vo pedesetite, Glasnik na INI, 41 (1-2): 64-68.

Trifunoski, J. (1955). Seoska naselja Skopskog Polja, Naselja i poreklo stanovništva, knj. 35, Srpski etnografski zbornik, 69.

Trifunoski, J. (1956). Preseljavanje Sandžačkih muslimana u Makedoniji, Glasnik srpskog geografskog društva, 36 (1): 61.

Trifunoski, J. (1958). O posleratnom naseljavanju stanovništva iz NR Makedonije u tri banatska naselja - Jabuka, Kačarevo i Glogonj. Matica srpska: Novi Sad.

Trifunoski, J. (1963). Slovenski iselenici od Albanija naceleni vo Vitolsko-Prilepskata Kotlina. Skopje: Prirodno-Matematički Fakultet na Univerzitetot Skopje.

Trifunoski, J. (1988). Albansko stanovništvo u Socijalističkoj Republici Makedoniji: antropogeografska i etnografska istraživanja. Beograd: Književne novine.

Van Selm, J. (2007). Macedonia: At a Quet Crossroads, Migration Information Source, http://www.migrationinformation.org/Profiles/display.cfm?ID=608 (20 June 2018).

Zdraveva, M. (1997). Preselbite od Makedonija po Karposhovoto vostanie. Materijali od nauchen sobir "Avstro-turska vojna (1683-1699), so poseben osvrt na Karposhovoto vostanie vo Makedonija", 5-7.10.1997, Kratovo i Ohrid. Skopje: Institut za nacionalna istorija, 187-202.

Zlotnik, H. (1999). Trends of International Migration since 1965: What Existing Data Reveal, International Migration, 37 (1): 21-61, doi: https://doi.org/10.1111/14682435.00065

\section{SOURCES}

Employment Service Agency of the Republic of Macedonia, http://www.avrm.gov.mk International Organization for Migration, https:/www.iom.int/world-migration Migration statistics review, 2005-2015, SSORM

OECD Statistics, https://stats.oecd.org/\#

Republic of Macedonia, Ministry of Interior, http://www.mvr.gov.mk/vest/1195

State statistical office of the Republic of Macedonia, http://www.stat.gov.mk/ PoslednoObjavenoVoMakstat_mk.aspx

State statistical office of the Republic of Macedonia, Population and social statistics, Migration 1994-2015, SSORM.

State statistical office of the Republic of Macedonia (2004-2016). Migracii 2005 - 2015., Skopje, http://www.stat.gov.mk/PoslednoObjavenoVoMakstat_mk.aspx 


\title{
Republika Makedonija - bezvremeni mozaik migracija
}

\author{
Biljana Apostolovska Toshevska, Mirjanka Madjevikj, Marija \\ Ljakoska, Svemir Gorin, Ivan Radevski, Olgica Dimitrovska
}

\begin{abstract}
SAŽETAK
Svrha je ovog rada prikazati prostorne i vremenske dimenzije međunarodnih migracija u Makedoniji. Rad se temelji na povijesnim dokumentima, od arhivskih podataka i objavljenih radova do suvremenih zapisa i podataka o useljavanju i iseljavanju, kao i na intervjuima s makedonskim državljanima koji žive u inozemstvu. Iseljavanje i useljavanje razmatraju se u dvama razdobljima: prvome, od najstarijih naselja na području današnje Makedonije do njezine neovisnosti stečene 1991., i drugome, od proglašenja neovisnosti do danas. U radu su predstavljeni samo najvažniji migracijski tokovi koji su utjecali na prostornu, ekonomsku, društvenu i kulturnu organizaciju države. Istaknuti su migracijski tokovi iz razdoblja Osmanskog Carstva, koji su snažno utjecali na trenutačni demografski sastav stanovništva Makedonije. No pruža se i pregled drugih tokova useljavanja u Makedoniju tijekom povijesti sve do danas. Dio rada odnosi se na noviju povijest i iseljavanje nakon 1964., kao i na iseljavanje državljana Makedonije nakon 1991. Iako su dostupne određene procjene, i dalje nema odgovora na pitanje koji je točan broj državljana Makedonije koji žive izvan domovine. Istodobno se $\mathrm{u}$ radu spominje zanimljiva tema intenzivnih tokova imigracije stranaca u Makedoniju u razdoblju nakon stjecanja neovisnosti, osobito onih iz Albanije, Turske i Kosova. Nasuprot useljavanju stranaca ističu se tokovi emigracije državljana Makedonije. Stoga je pozitivni migracijski saldo u državi rezultat useljavanja stranaca s privremenim i produljenim boravkom. Istodobno je Makedonija i dio balkanske migrantske rute za migrante iz azijskih i afričkih zemalja.
\end{abstract}

KLJUČNE RIJEČI: emigracija, imigracija, Republika Makedonija 